\title{
Effects of Atmospheric Pollutants on Children Asthma Outbreaks
}

\author{
Ben Zion Garty, ${ }^{2}$ Evsey Kosman, ${ }^{1}$ Eliezer Ganor, ${ }^{3}$ Niv Alon, ${ }^{2}$ Neta Kibilis, ${ }^{2}$ Joseph Garty, ${ }^{2}$ Marc \\ Mimouni, ${ }^{2}$ and Yoav Waisel ${ }^{1, *}$ \\ ${ }^{I}$ Department of Plant Sciences, Tel Aviv University, Tel Aviv, Israel \\ ${ }^{2}$ Kipper Institute of Pediatric Allergy and Immunology, and Pediatric Emergency Department, Schneider Children's \\ Medical Center of Israel, Petah Tiqva, Israel \\ ${ }^{3}$ Dept of Geophysics and Planetary Sciences, Tel Aviv University, Israel
}

\begin{abstract}
The effects of air pollutants, weather conditions, airborne pollen and spores on the incidence of emergency room (ER) visits of children for acute asthma attacks were investigated.

One-year retrospective study was done. Data on daily concentrations of air pollutants, airborne allergens and weather conditions were collected and compared with the ER visits of 2431 asthmatic children (age 1-18 years) in the Schneider Medical Center, near Tel Aviv.

ER visits of asthmatic children showed a negative correlation with the measured $\mathrm{O}_{3}$ concentrations and with extreme ambient temperatures. A positive correlation was found with high barometric pressure with $\mathrm{NO}_{2}$ and $\mathrm{SO}_{2}$ concentrations. An exceptionally high incidence of ER visits of asthmatic children was observed during September, coinciding with the beginning of the school year. When September was excluded from the annual calculations the correlation between ER visits and environmental factors increased. $49 \%$ of the variance of ER visits were explained by $\mathrm{O}_{3}$ alone, $46 \%$ by $\mathrm{NO}_{2}$ alone, $54 \%$ by $\mathrm{O}_{3}+\mathrm{NO}_{2}$, and $31 \%$ by weather parameters. $58 \%$ of the variation was explained by the combination of air pollutants and weather parameters. Airborne particulates did not show any meaningful correlation with ER visits.

The major factors associated with severe asthma attacks were high $\mathrm{NO}_{2}$ and $\mathrm{SO}_{2}$. The negative correlation with $\mathrm{O}_{3}$ implies that at certain concentrations, $\mathrm{O}_{3}$ may have a beneficial effect. The particularly high number of ER visits at the beginning of the school year was presumably associated with an increase in viral infections combined with emotional stresses.
\end{abstract}

A worldwide increase in prevalence of asthma is well known [1-4]. A seasonal incidence of asthma attacks, especially in children is also well documented [5-7]. Aggravation of asthma is associated with respiratory infections, emotional stress, exposure to allergens, extreme weather conditions and air pollution [8-13]. However, the specific contribution of each of the pollutants to manifestation of asthma remains controversial [9-14].

Air pollutants comprise a serious hazards to the population's health in general, and to allergic patients in particular. However, while the aggravating effects of $\mathrm{SO}_{2}$ and $\mathrm{NO}_{2}$ are well established, contradictory data have been presented regarding the effects of $\mathrm{O}_{3}$. For example, some studies have shown that an increase in $\mathrm{O}_{3}$ concentration correlates positively with increased hospital admissions of asthmatic children [7,9,15-17]. Others have found the contrary, i.e., that under certain conditions ozone concentrations are negatively correlated with ER visits of asthmatic children and may have a "protective" effect $[18,19]$. An apparent reverse correlation between $\mathrm{O}_{3}$ concentration and asthma morbidity was also shown [5].

*Address correspondence to this author at the Department of Plant Sciences, TAU, Tel Aviv 69978, Israel; Tel: 972-3-640 9189;

E-mail: waisel@post.tau.ac.il
In order to clarify this issue, we reinvestigated the correlations between ozone, as well as of other environmental factors, and ER visits of asthmatic children.

\section{SUBJECTS AND METHODS}

\section{Patients}

The study population included all 2431 asthmatic children who presented at the pediatric Emergency Room (ER) of the Schneider Children's Medical Center of Israel from January 1 to December 31, 1995. The hospital receives patients from the whole Tel Aviv metropolitan area, where the environmental monitoring was done. There were 1556 boys (64\%) and 875 girls (36\%) ranging in age from 1 to 18 years. Children with wheezing under the age of 12 months were excluded from the study because of a possible confusion bronchiolitis. The data was extracted from the Hospital's ER records. The search was for Asthma, Wheezing, Children and for Allergy symptoms. The data was compiled into weekly clusters because the availability of public medical services in Israel differs through the week: on Sundays through Thursdays, the public clinics are open, but on Fridays and Saturdays, patients have access only to ER services.

\section{Environmental Factors}

The following environmental factors were measured in the center of Tel Aviv. 


\section{Air Pollutants}

Data on ozone $\left(\mathrm{O}_{3}\right)$, nitrogen oxide $\left(\mathrm{NO}_{2}\right)$, sulfur dioxide $\left(\mathrm{SO}_{2}\right)$ and particulates were obtained from the monitoring stations of the Ministry of the Environment and from the Electric Company of Israel. Measurements were taken every half-hour, but calculated as the daily average (0-24 hr). Ozone was monitored with a UV photometric ozone analyzer (Model 8810, Motor Labs); $\mathrm{NO}_{2}$ by chemiluminescence with a $\mathrm{NO}_{2}$ Analyzer (Model 8840, ML Monitoring Labs); $\mathrm{SO}_{2}$ with a pulse fluorescence $\mathrm{SO}_{2}$ analyzer (Model 43A, Thermo Electron Instruments); and particulates $\left(\mathrm{PM}_{10}\right)$ with an ambient particle monitor (Team Series 14001).

\section{Airborne Allergens}

Monitoring was performed with a pollen trap (Burkard Manufacturing Co., Rickmansworth, UK) and several Rotorod samplers (Model 1987, sampling Technologies, Inc., CA, USA). The pollen and spores were identified and counted by light microscopy, and their concentration was calculated according to the manufacturer's instructions. Special attention was addressed to the presence of the allergenic pollen of Artemisia, Cupressus, Olea and Parietaria, to pollen of the Poaceae, Chenopodiaceae and Amaranthaceae, as well as to the spores of Alternaria, Cladosporium and Stemphylium.

\section{Weather Parameters}

Data on daily temperatures, relative humidity and barometric pressure were obtained from the Meteorological Service of Israel.

\section{Statistical Analysis}

Data analysis was performed using Statistix 3.5 software package (Analytical Software, St. Paul, MN, USA).

Pearson's correlations ( $r$ ) were calculated to establish relationships between the daily number of ER visits and each of the environmental parameters. Multiple correlation coefficients $(\mathrm{R})$ were used to determine how much of the variance of the ER visits could be explained by a given set of environmental parameters.

The running means were used in order to identify the pattern of the relationships between the environmental effectors and the ER visits of asthmatic children without the subjective fixation of an artificial period of time.

The running mean of a variable for $n$ days was defined as the values of the variable $x$ measured on the first, second, third day, etc. The running mean $(r x)$ for $n$ days is:

$$
r x_{i}=\frac{1}{n} \cdot \sum_{k=i}^{n+i-1} x_{k}, i=1,2,3, \ldots
$$

The running mean of a variable for one week $(n=7)$ was calculated as the mean from Monday to Sunday, then from Tuesday to Monday, than from Wednesday to Tuesday, etc.

Various sets of independent variables were formed from the corresponding running means of each of the environmental parameters.

Analysis of the data using the Poisson regression was done by the S-Plus software using the function for general linear models (GLM). P values (for F-statistics) were calculated to determine the significance of the regression relationships.

\section{RESULTS}

The number of children with acute asthma seen in the ER, and the percentage of such children of the total number of patients seen in the ER (Figs. 1, 2) yielded a clear seasonal pattern. In general, asthma morbidity was higher in the autumn and winter and lower in late spring and summer.

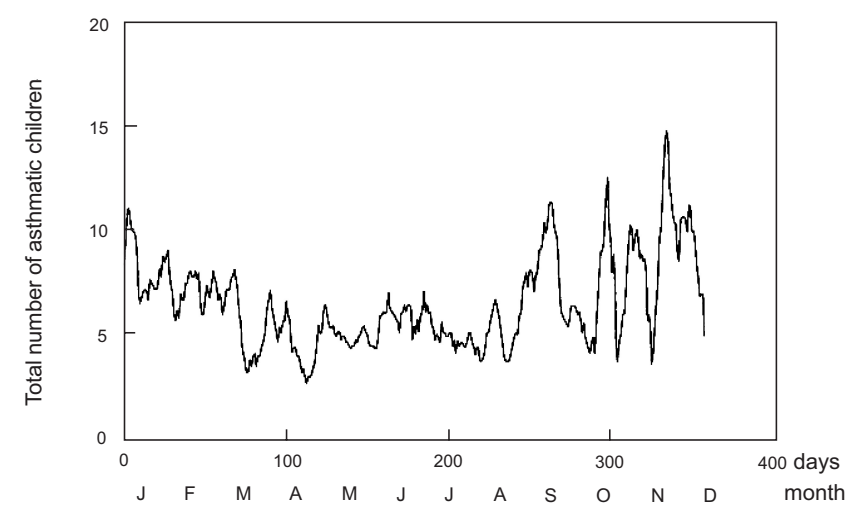

Fig. (1). Patients seen in the ER during 1995.

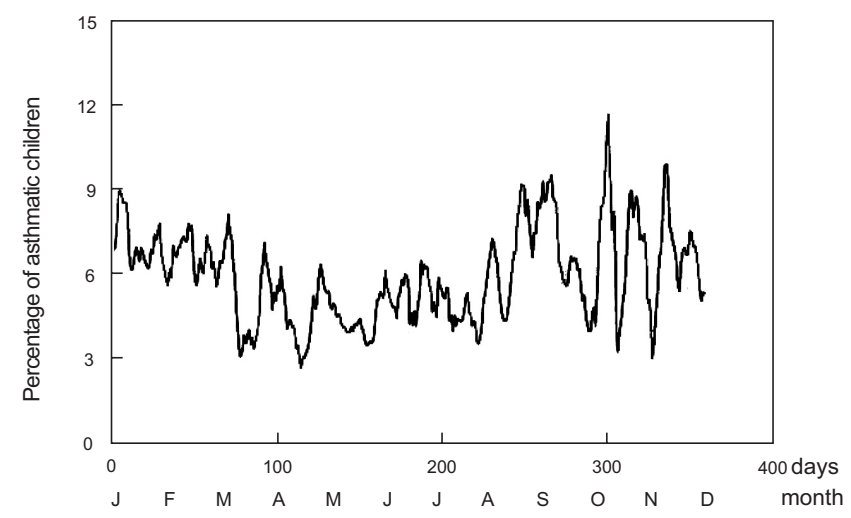

Fig. (2). Percentage of asthmatic children out of total number of patients.

The 7 days running mean of the ER visits was compared with the corresponding running mean of each of the environmental parameters (Table 1). Among the environmental parameters, $\mathrm{NO}_{2}$ and $\mathrm{SO}_{2}$, were highly correlated with each other, both showing a seasonal pattern. A positive correlation was establishing between ER visits and ambient concentrations of $\mathrm{NO}_{2}$ (Fig. 6), $\mathrm{SO}_{2}$ (Fig. 7) and barometric pressure (Fig. 8; Table 1). ER visits showed a negative correlation with changes in $\mathrm{O}_{3}$ concentrations (Tables 1, Fig. 3) and with minimal and maximal temperatures (Figs. 4, 5). However, the negative correlation between ER visits and the two later parameters was very low (0.27 and 0.29$)$.

ER visits were exceptionally high during September. Apparently, additional factors played during September a role in the increased asthma outbreak. When the variables for this month were omitted from the annual calculation, the correlation coefficients improved dramatically, being more negative 
Table 1. Pearson Correlation Coefficient (r) Between ER Visits of Asthmatic Children and Various Environmental Factors

\begin{tabular}{|c|c|c|}
\hline \multirow{2}{*}{ Factor } & \multicolumn{2}{|c|}{ Running Mean for 7 days } \\
\cline { 2 - 3 } & 12 Months & 11 Month* \\
\hline \hline $\mathrm{O}_{3}$ & -0.61 & -0.70 \\
$\mathrm{NO}_{2}$ & 0.59 & 0.68 \\
$\mathrm{SO}_{2}$ & 0.50 & 0.60 \\
Particulates $\left(\mathrm{PM}_{10)}\right.$ & 0.32 & 0.33 \\
Barometric pressure & 0.49 & 0.54 \\
Minimal temperature & -0.27 & -0.40 \\
Maximal temperature & -0.29 & -0.42 \\
Relative humidity & -0.21 & -0.22 \\
\end{tabular}

* Excluding September

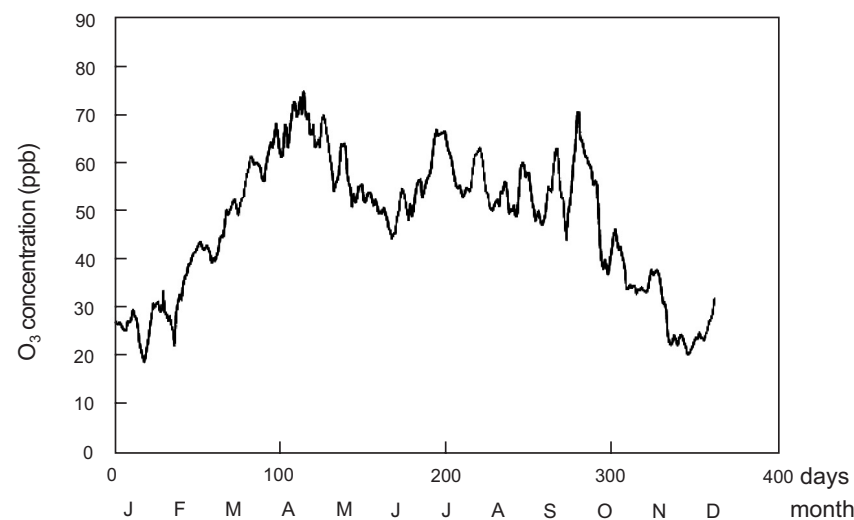

Fig. (3). Annual changes in $\mathrm{O}_{3}$ concentration.

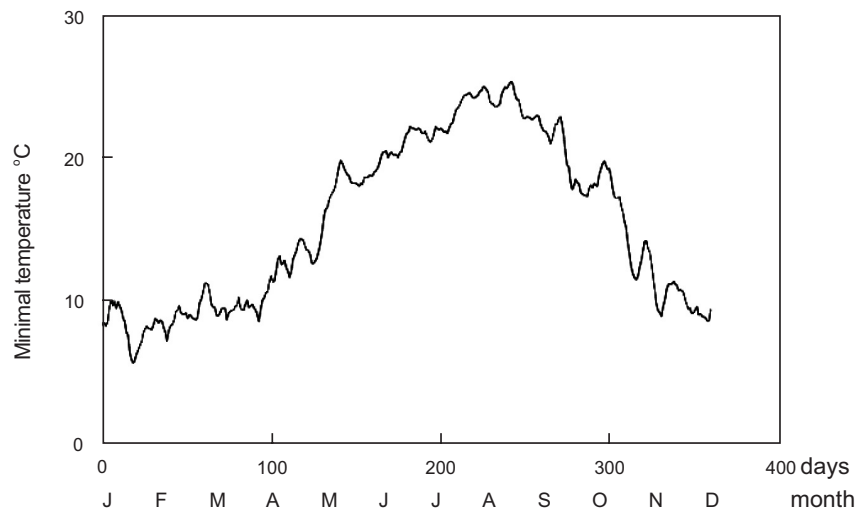

Fig. (4). Annual changes in Minimal temperature.

with $\mathrm{O}_{3}$ concentrations $(\mathrm{r}=-0.70)$, with minimal temperatures $(\mathrm{r}=-0.40)$ and maximal temperatures $(\mathrm{r}=-.42)$ (Table 1), and more positive with concentrations of $\mathrm{NO}_{2}(\mathrm{r}=0.68), \mathrm{SO}_{2}$ $(\mathrm{r}=0.60)$ and high barometric pressure $(\mathrm{r}=0.54)$. The correlation between ER visits and airborne particulates $\left(\mathrm{PM}_{10}\right)$ (Fig. 9) or between ER visits and RH (Fig. 10) was low, except for the month of September.

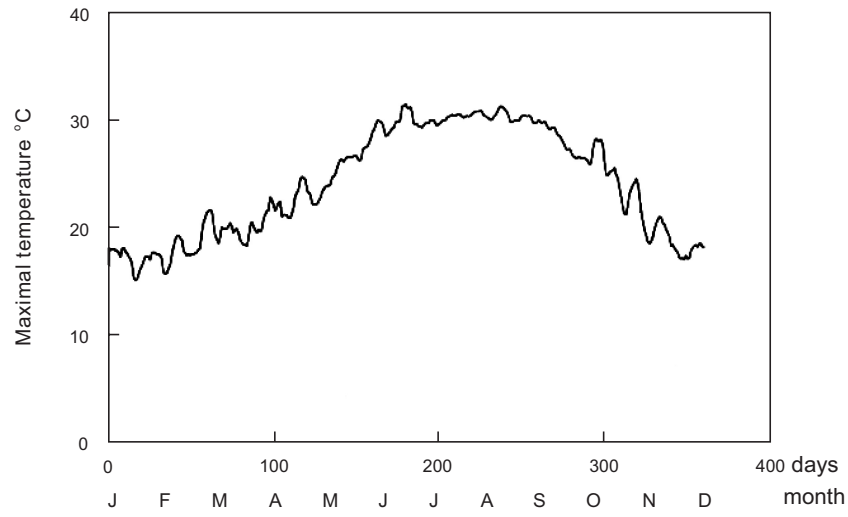

Fig. (5). Annual changes in Maximal temperature.

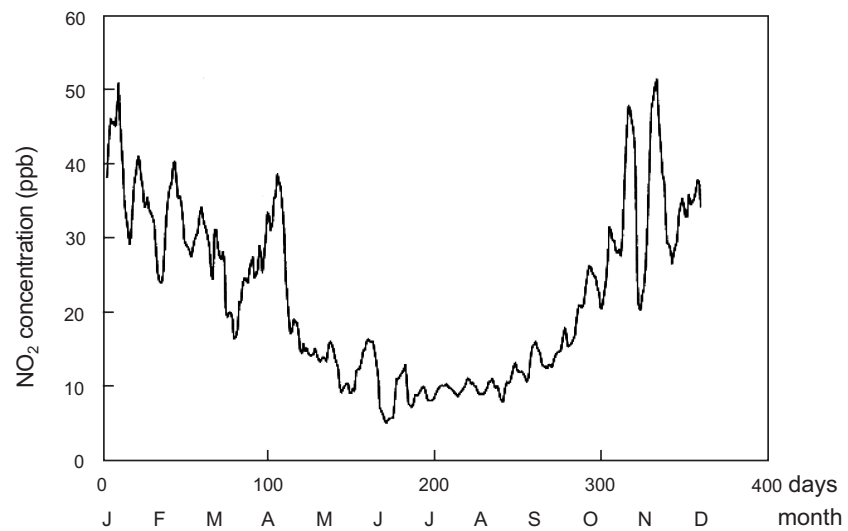

Fig. (6). Annual changes in $\mathrm{NO}_{2}$ concentration in the air.

The concentrations of airborne pollen varied with the flowering season of each species. It was maximal during the spring (Fig. 11). However, none of the pollen was significantly correlated with ER visits. A positive correlation was found between ER visits and concentrations of airborne spores (Fig. 12). 




Fig. (7). Annual changes in $\mathrm{SO}_{2}$ concentration in the air.

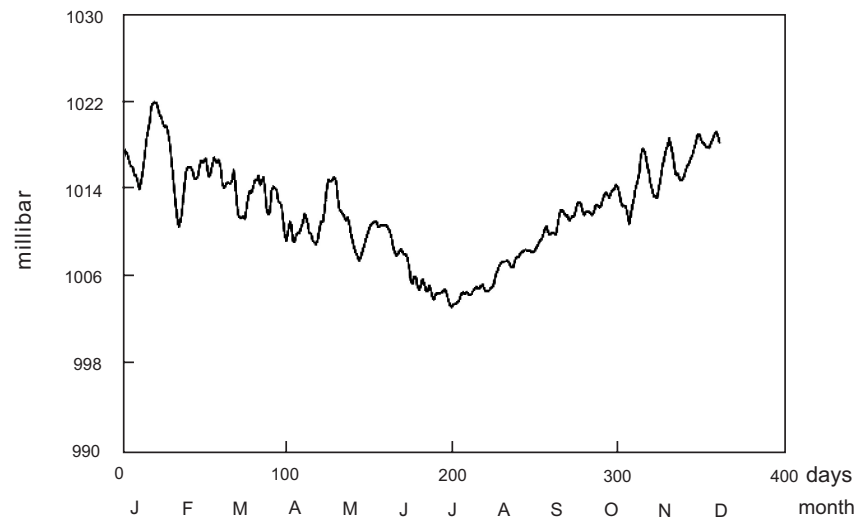

Fig. (8). Annual changes in Barometric pressure.

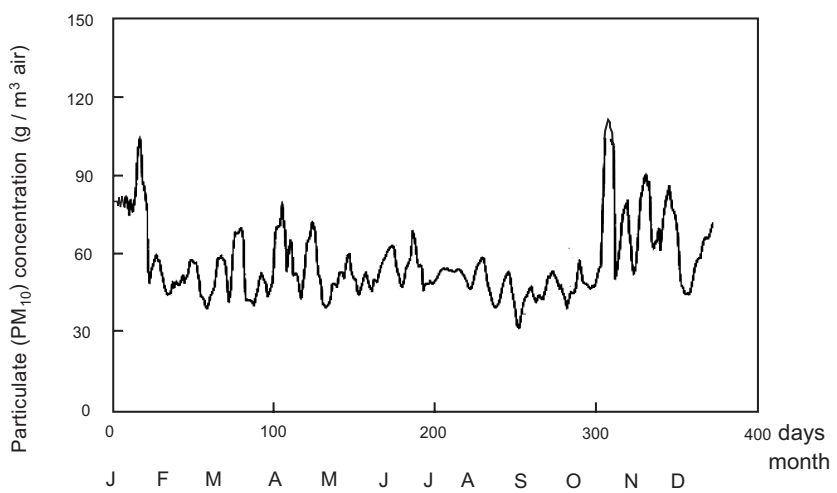

Fig. (9). Annual changes in Particulate $\left(\mathrm{PM}_{10}\right)$ concentration.

The deviation from the mean annual ER visits has shown that approximately $37 \%$ of the variance in the number of ER visits during the entire year was explained by fluctuations in $\mathrm{O}_{3}, 35 \%$ by $\mathrm{NO}_{2} ; 25 \%$ by $\mathrm{SO}_{2}$, and $24 \%$ by barometric pressure. Changes in the minimal and maximal temperatures explained only $7 \%$ and $8 \%$ of the variance and therefore cannot be considered as major effectors. When the data for September were excluded, $\mathrm{O}_{3}$ alone explained $49 \%$ of the variance, $\mathrm{NO}_{2}$ explained $46 \%$ of the variance, $\mathrm{SO}_{2}$ explained $36 \%$, barometric pressure $28 \%$, minimal temperature $16 \%$ and maximal temperature $18 \%$ (Table 2 ). Regression analy-

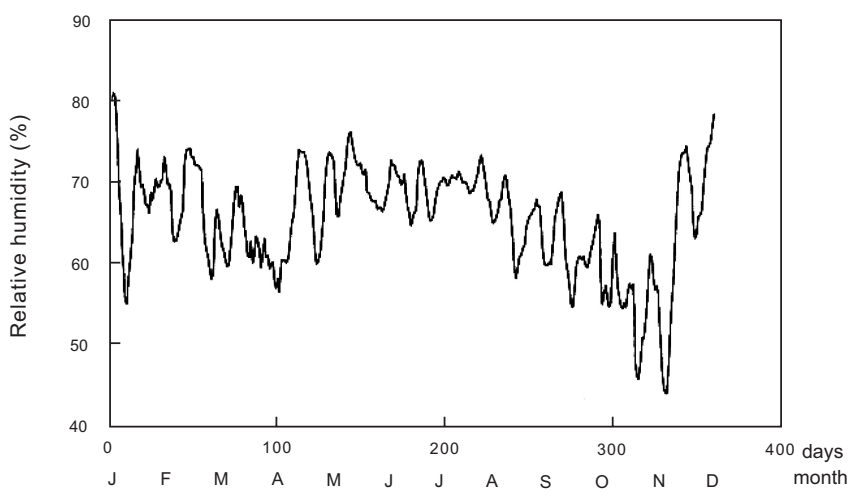

Fig. (10). Annual changes in Relative humidity.



Fig. (11). Annual changes in airborne pollen count.

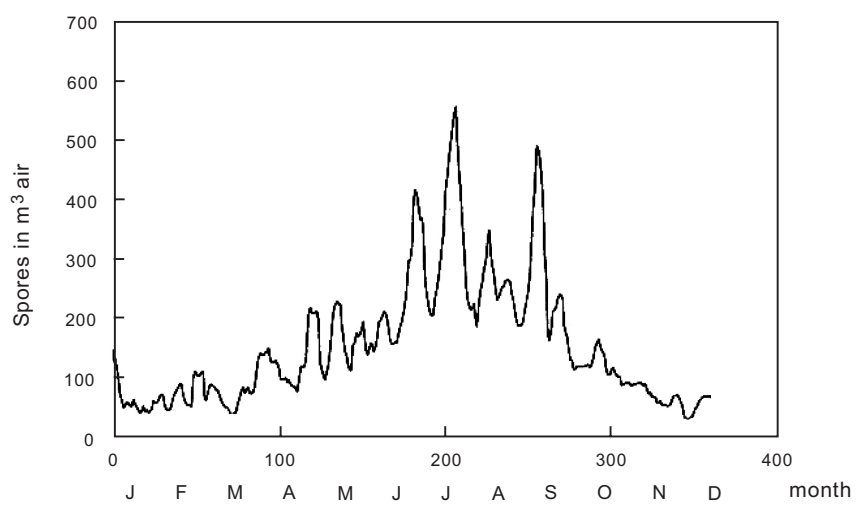

Fig. (12). Annual changes in airborne spore count.

sis of sets of parameters revealed that $54 \%$ of the variance of the weekly running mean of ER visits was explained by $\mathrm{O}_{3}+$ $\mathrm{NO}_{2}$ or by $\mathrm{O}_{3}+\mathrm{NO}_{2}+\mathrm{SO}_{2}$. The set of weather parameters explained $31 \%$ of the variance. The set of all air pollution and weather parameters calculated for the 11-month period (without September) explained $58 \%$ of the weekly variance (Table 2).

Statistical analysis (F-test) of the correlation between the individual environmental factors and ER visits of asthmatic children and multiple regression analysis of ER visits versus 
Table 2. Effects of Individual and Combined Environmental Factors (Multiple Regression Analysis) on Variance of 7-day Running Mean of ER Visits of Asthmatic Patients for 11 Month (Excluding September)

\begin{tabular}{|c|c|}
\hline Factor & $\begin{array}{c}\text { Percent of Variance of ER Visits of Asthmatic Children } \\
\text { Explained by Factor }\end{array}$ \\
\hline \hline Polluting gases & 49 \\
$\mathrm{O}_{3}$ & 46 \\
$\mathrm{NO}_{2}$ & 36 \\
$\mathrm{SO}_{2}$ & 54 \\
$\mathrm{O}_{3}+\mathrm{NO}_{2}$ & 54 \\
$\mathrm{O}_{3}+\mathrm{NO}_{2}+\mathrm{SO}_{2}$ & 28 \\
$\mathrm{Weather} \mathrm{parameters}^{\text {Barometric pressure }}$ & 16 \\
Minimal temperature & 18 \\
\hline Maximal temperature & \\
\hline Combined parameters & 31 \\
\hline $\mathrm{Barometric}$ pressure + minimal and maximal temperatures + relative humidity & 55 \\
$\mathrm{O}_{3}+\mathrm{NO}_{2}+\mathrm{SO}_{2}+$ barometric pressure & \\
\hline All parameters & 58 \\
\hline $\mathrm{O}_{3}+\mathrm{NO}_{2}+\mathrm{SO}_{2}+$ particulates + barometric pressure + minimal and maximal tempera- \\
ture + relative humidity & \\
\hline
\end{tabular}

$\mathrm{P}<0.001$ for all values

the sets of environmental factors yielded highly significant values $(\mathrm{p}<0.001)$.

\section{DISCUSSION}

Air pollution is a serious health hazard, especially for people with allergic diseases. A significant connection between air pollution and respiratory symptoms or with increased use of bronchodilators was noted $[9,10,19,20]$.

Polluted air contains a mixture of substances. $\mathrm{NO}_{2}$ causes increased bronchial reactivity in asthmatic children, potentiate $s$ the effects of other gaseous air pollutants [20,21] and of airborne plant allergens [9, 21-23]. People with asthma are particularly sensitive to high $\mathrm{SO}_{2}$ concentrations [22, 24]. Exposure to $\mathrm{SO}_{2}$ causes airway inflammation which is manifested by increased numbers of mast cells, alveolar macrophages and lymphocytes in the bronchoalveolar lavage.

The smaller particles $\left(\mathrm{PM}_{10}\right)$, a mixture of smoke, minerals and organic dust, seem to enter readily into the respiratory tract and to cause irritation of the lungs [10, 25] and asthma exacerbation $[19,20,26]$. Thus, it is interesting to note that according to our results, airborne particulates $\left(\mathrm{PM}_{10}\right)$ were not significantly correlated with the annual ER visits of asthmatic children, except for the month of September. During this month airborne particulates have probably contributed to asthma morbidity in addition to the "background" morbidity during the rest of the year.

Several environmental factors were correlated with severe asthma morbidity in children. In general, the effect of gaseous air pollutants throughout the year was stronger than that of extreme weather conditions. Negative correlations were established between $\mathrm{ER}$ visits and $\mathrm{O}_{3}$ concentrations whereas positive correlations were found with $\mathrm{NO}_{2}, \mathrm{SO}_{2}$ and high barometric pressure.
When the data for September were excluded from the annual calculations, the correlation between the ER visits and the combined environmental conditions was significantly improved. September is the beginning of the kindergarten and school year, causing high psychological stresses and an increased incidence of viral infections [27]. Still, the effects of other confounding factors e.g., $\mathrm{PM}_{10}$, can not be ruled out $[28,29]$.

In the present study, as well as in our previous one [18], ozone concentrations correlated negatively with ER visits of asthmatic children. Ozone is generally known as a potentially damaging factor, affecting the respiratory tract tissues. The effects of ozone on the airways depends on its concentration, the duration of exposure, and the intensity of the subjects physical activity $[14,17,30]$. According to WHO recommendations, the threshold for ozone exposure are 76-100 ppb for 1 hour or 50-60 ppb for 8 hours [31]. Concentrations of $\sim 120 \mathrm{ppb}$ can increase bronchial responsiveness to allergens in asthmatic patients, without affecting their baseline pulmonary functions [32]. Higher concentrations of $\mathrm{O}_{3}(200-$ $400 \mathrm{ppb}$ ) cause bronchial hyperactivity. The mechanisms underlying such relationships remain unclear and conflicting data were presented. Some authors have postulated that ozone causes an inflammatory reaction with vasodilatation and greater absorption of allergens [32]. Results of others failed to show significant changes until a threshold concentration of approximately $40 \mathrm{ppb}$ was reached [33-37].

Reports from Vancouver [15], Seattle [38] and central USA [35] showed that ozone levels were either uncorrelated with asthma incidence or were inversely correlated with daily asthma attack rates [36]. A positive correlation between ER visits of asthmatic children and $\mathrm{O}_{3}$ was reported from Spain, France and Singapore [39-42]. On the other hand, a 
negative correlation between certain ozone concentrations and ER visits of wheezing children, indicated that certain $\mathrm{O}_{3}$ concentrations can be protective [19].

Seasonality in childhood asthma morbidity has been found in an extensive study (NCICAS) which included eight major cities in the United States [5]. The authors speculated that the cause of the seasonality was viral respiratory infections. No correlation between childhood asthma and $\mathrm{O}_{3}$ concentration was found in this study, though an apparent reverse relationship can be seen between wheezing and $\mathrm{O}_{3}$ concentration [5].

A significant negative correlation between previous day ozone concentration and several lung function parameters (forced vital capacity and expiratory flow) was found for children in the Netherlands [16].

Ozone can prime the bronchial airways for increased responses to subsequently encountered allergens [43] or air pollutants [44] and the effect of ozone may depend on a second insult. Support for this hypothesis was found in the time lag observed between exposure to ozone and a decrease in forced vital capacity $[45,46]$.

It is somewhat astonishing that no meaningful correlation was found in our study between the number of ER visits and the recorded levels of airborne pollen and spores. However, the lack of information regarding possible allergic responses of each of the examined patients to specific allergens prevented us from exploring the individual correlation between specific airborne allergens and asthma exacerbation.

The effects of individual environmental factors are intensified when they act in concert. Previous studies have shown that the combination of air pollutants with certain weather conditions has a cumulative effect on asthma exacerbation [11-12, 47]. The present study supports this concept. Most epidemiological studies on effects of pollution on human health are limited by the absence of information on the actual exposure of individual patients. Nevertheless, our data support the hypothesis that certain combinations of air pollutants, and weather parameters, are highly correlated with severe wheezing in children.

The superfluous number of ER visits of asthmatic children during September is interesting because it coincided with the beginning of the kindergarten and school year which may involve increased exposure to viral infections [8] and to psychological stresses. [5].

A similar observation was reported from Brighton (UK)

In conclusion, the present study raised at least two crucial points: a) The seasonality of asthma morbidity with a definite increase in ER visits of asthmatic children during September; b) The apparent "protective" effect of certain ozone concentrations on asthma exacerbations.

\section{ACKNOWLEDGMENT}

The authors thank the Israel Electric Company and the Meteorological Service of Israel for the environmental data; and Charlotte Sachs and Gloria Ginzach for their assistance.

\section{REFERENCES}

[1] Weitzman M, Gortmaker SL, Sobol, et al. Recent trends in prevalence and severity of childhood asthma. J Am Med Assoc 1992; 268: 2673-7.

[2] Burr MI, Mutland BK, King S, et al. Changing asthma prevalence: two surveys 15 years apart. Arch Dis Child 1989; 64:1452-6.

[3] Evans R, Mullally DI, Wilson RW. National trends in morbidity and mortality of asthma in the US: prevalence, hospitalization and death from asthma over two decades: 1965-1984. Chest 1987; 91 : 652-74.

[4] Burney PGJ. Asthma mortality in England and Wales: evidence for a further increase: 1974-84. Lancet 1986; 2: 323-6.

[5] Gergen PJ, Mitchell H, Lynn H. Understanding the seasonal pattern of childhood asthma: results from the National Cooperative InnerCity Asthma Study (NCICAS). J Pediatr 2002; 141: 31-6.

[6] Britton J, Chinn S, Burney, et al. Seasonal variation in bronchial reactivity in a community population. J Allergy Clin Immunol 1988; 82: 134-9.

[7] Bates DV, Sizto R. Air pollution and hospital admissions in southern Ontario: the acid summer haze effect. Environ Res 1987; 43: 317-31.

[8] Folkerts G, Busse WW, Nijkamp FP, et al. Viruses induced airway hyperresponsiveness and asthma. Am J Respir Crit Care Med 1997; 157: 1708-20.

[9] Pierson WE, Koenig JW. Respiratory effect of air pollution on allergic disease. J Allergy Clin Immunol 1992; 90: 557-66.

[10] Burr M. Pollution: does it cause asthma? Arch Dis Child 1995; 72 . 377-87.

[11] Sutherland A, Hall IP. Thunderstorms and asthma admissions. Lancet 1994; 344: 1503-4.

[12] Check WA. Common mushroom spores may cause asthma and hay fever in fall. J Am Med Assoc 1982; 247: 2071.

[13] Delfino RJ, Coate BD, Zeiger RS, et al. Daily asthma severity in relation to personal ozone exposure and outdoor fungal spores. Am J Respir Crit Care Med 1996; 154: 633-41.

[14] Muehlendahl KE. Ozone toxicity-an environmental dilemma. Eur J Pediatr 1997; 156: 734-5.

[15] Bates DV, Baker-Anderson M, Sitzo R. Asthma attack periodicity: a study of hospital emergency visits in Vancouver. Environ Res 1990; 51: 51-70.

[16] Hoek G, Fischer P, Brunekreef B, et al. Acute effects of ambient ozone on pulmonary function of children in the Netherlands. Am Rev Respir Dis 1993; 147: 111-7.

[17] Higgins IT, D'Arcy JB, Gibbsons DI, et al. Effects of exposures to ambient ozone on ventilatory lung function in children. Am Rev Respir Dis 1990; 141: 1136-46.

[18] Garty BZ, Kosman E, Ganor E, et al. Emergency room visits of asthmatic children: relation to air pollution, weather and airborne allergens. Ann Allergy 1998; 81: 563-70.

[19] Buchdahl R, Parker A, Stebbings T, et al. Association between air pollution and acute childhood wheezing: episodes prospective observational study. Br Med J 1996; 312: 661-5.

20] Barnes PJ. Air pollution and asthma: molecular mechanisms. Mol Med Today 1995; 1: 149-55.

[21] Hazucha MJ, Folinshee LJ, Seal E, et al. Lung function response of healthy women after sequential exposures to $\mathrm{NO}_{2}$ and $\mathrm{O}_{3}$. Am $\mathrm{J}$ Respir Crit Med 1994; 150: 642-7.

[22] Devalia Jl, Rusznak C, Herdman MJ, et al. Effect of nitrogen dioxide and sulphur dioxide on airway responses of mild asthmatic patients to allergen inhalation. Lancet 1994; 344: 1668-71.

[23] Tunnicliffe WS, Burge PS, Ayres JG. Effect of domestic concentrations of nitrogen dioxide on airway responses to inhaled allergen in asthmatic patients. Lancet 1994; 344: 1733-6.

[24] Linn WS, Avol EL, Peng RC, et al, Replicated dose response study of sulfur dioxide effects in normal, atopic and asthmatic volunteers. Am Rev Respir Dis 1987; 126: 1127-34.

[25] Strachan DP. The role of environmental factors in asthma. Br Med Bull 2000; 56: 865-82.

[26] Peden DB. Air pollution in asthma: effect of pollutants on airway inflammation. Ann Allergy Asthma Immunol 2001; 87: 12-7.

[27] Storr J, Lenney W. School holidays and admissions with asthma. Arch Dis Child 1989; 64: 103-7.

[28] Lannerö E, Kull I, Wickman M, et al. Environmental risk factors for allergy and socioeconomic status in a birth cohort (BAMSE). Pediatr Allergy Immunol 2002; 13: 182-7. 
[29] Johnston SL. The role of viral and atypical bacterial pathogens in asthma pathogenesis. Pediatr Pulmonol 1999; 18: 141-3.

[30] Spektor DM, Thurstom GD, Mao J, et al. Effect of single and multiple ozone exposures on respiratory function in active normal children. Environ Res 1991; 55: 107-22.

[31] WHO. Ozone and other photochemical oxidants. Air quality guidelines for Europe. European Series, WHO Regional Publications: Copenhagen 1987; 23: pp. 315-326.

[32] Molfino NA, Wright SC, Katz I, et al. Effect of low concentration of ozone on inhaled allergen responses in asthmatic subsets. Lancet 1991; 338: 199-203.

[33] Lierl MB, Hornung RW. Relationship of outdoor air quality to pediatric asthma exacerbations. Ann Allergy Asthma Immunol 2003; 90: 28-33

[34] Schwartz J. Lung function and chronic exposure to air pollution: a cross-sectional analysis of NHANES II. Environ Res 1989; 50: 309-21.

[35] Zwick H, Popp W, Wagner C, et al. Effects of ozone on the respiratory health, allergic sensitization and cellular immune system in children. Am Rev Respir Dis 1991; 144: 1075-9.

[36] Cody RP, Weiel CP, Birnbaum G, et al. The effect of ozone associated with summertime photochemical smog in the frequency of asthma visits to hospital emergency departments. Environ Res 1992; 58: 184-94.

[37] Richards W, Azen SP, Weiss J, et al. Los Angeles air pollution and asthma in children. Ann Allergy 1981; 47: 348-53.

[38] Schwartz J, Slater D, Aron TV, et al. Particular air pollution and hospital emergency room visits for asthma in Seattle. Am Rev Respir Dis 1993; 147:826-31.
[39] Sunyer J, Basagana X, Belmmonte J, et al. Effect of nitrogen dioxide and ozone on the risk of dying in patients with severe asthma. Thorax 2002; 57: 687-93.

[40] Fauroux B, Sampil M, Quenel P, et al. Ozone: a trigger for hospital pediatric asthma emergency room visits. Pediatr Pulmonol 2000; 30: 41-6.

[41] Chew FT, Goh DY T, Ooi C, et al. Association of ambient airpollution levels with acute asthma exacerbation among children in Singapore. Allergy 1999; 54: 320-9.

[42] Edwards J, Walter S, Griffiths RK. Hospital admissions for asthma in preschool children: Relationship to major roads in Birmingham, United Kingdom. Arch Environ Health 1994; 49: 223-7.

[43] Peden DB. The effects of air pollution in asthma and respiratory allergy. The American experience. Allergy Clin Immunol 1995; 7 : 19-23.

[44] Koenig JQ, Covert DS, Hanley Q, et al. Prior exposure to ozone potentiates subsequent response to sulfur dioxide in adolescent asthmatic subjects. Am Rev Respir Dis 1990; 141: 377-80.

[45] Lioy PJ, Vollmuth TA, Lippmann M. Persistence of peak flow decrement in children following ozone exposures exceeding the national ambient air quality standard. J Air Pollut Control Assoc 1985; 35: 1068-71

[46] Spannhake EW, Reddy SP, Jacoby, et al. Synergism between rhinovirus infection and oxidant pollutant exposure enhances airway epithelial cell cytokine production. Environ Health Perspect 2002; 110: 665-70.

[47] Mosteller F, Tukey JM. Data analysis and regression. AddisonWesley Publishing Co., UK 1977; pp. 52-53.

(C) Garty et al.; Licensee Bentham Open.

This is an open access article licensed under the terms of the Creative Commons Attribution Non-Commercial License (http://creativecommons.org/licenses/by-nc/3.0/) which permits unrestricted, non-commercial use, distribution and reproduction in any medium, provided the work is properly cited. 